\title{
A Dangerous but Lovely Approach: Extracranial Kissing Carotids
}

\author{
Tehlikeli ancak Güzel Bir Yaklaşım; Ekstrakranial Öpüşen Karotisler
}

Keywords: Kissing carotids, retropharyngeal, CT angiography

Anahtar Kelimeler: Öpüşen karotisler, retrofaringeal, BT anjiyografi

\section{Dear editor,}

"Kissing carotids" is the term used to define an anatomical variation of the cervical carotid arteries, which are tortuous and elongated and come in close proximity at the midline. This can be retropharyngeal (extracranial) or retrosphenoid (intracranial). It is usually encountered in an asymptomatic patient during a routine head and neck examination. In cases of retropharyngeal internal carotid arteries (ICAs), presenting complaints may include dysphagia, abnormal voice, obstructive sleep apnea, or a sense of a foreign body $(1,2,3)$. This midline approach sometimes remains unrequited as seen in unilateral cases (4). We present the case of a 55-year-old woman who complained of long standing abnormal voice and hoarseness. Contrast-enhanced computed tomography of the head showed that the bilateral cervical ICAs were in close proximity to each other in the retropharyngeal space. The minimum distance from the posterior pharyngeal walls was $1.8 \mathrm{~mm}$ for the right ICA and $3 \mathrm{~mm}$ for the left ICA (Figure 1).

Normally, although the cervical ICA has a straight course in the neck as opposed to its intracranial tortuosity, in relation to age, morphological variations are not rare, which were encountered in the form of tortuosity, kinking, or coiling with no demonstrated additive risk of stroke $(1,5)$. However, in cases of retropharyngeal kissing carotids, tortuosity is of clinical importance because of the

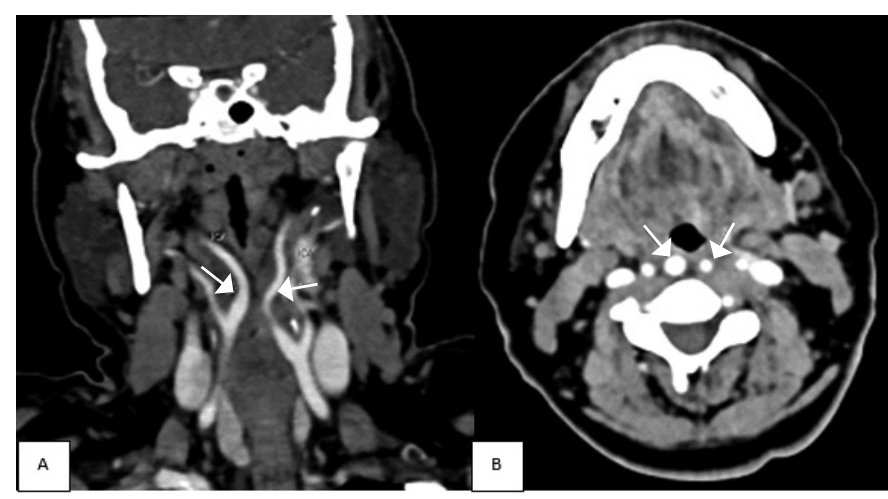

Figure 1. A) Coronal and B) axial computed tomography angiography images show the meeting of the bilateral internal carotid arteries at the midline (A, arrows) and the close proximity of the internal carotid arteries to the posterior pharyngeal walls (B, arrows)

risk of injury during retropharyngeal intervention and anesthetic procedures. Therefore, knowledge about this variation is important and should be reported to avoid catastrophic complications.

Address for Correspondence/Yazişma Adresi: Berrin Erok MD, University of Health Sciences Turkey, Prof. Dr. Cemil Tascioglu City Hospital, Clinic of Radiology, Istanbul, Turkey

Phone: +90 5302604150 E-mail: drberrinerok@hotmail.com ORCID: orcid.org/0000-0001-8036-547X

Received/Geliş Tarihi: 07.04.2021 Accepted/Kabul Tarihi: 03.12.2021

${ }^{\circ}$ Copyright 2021 by Turkish Neurological Society

Turkish Journal of Neurology published by Galenos Publishing House. 


\section{Ethics}

Informed Consent: Written consent was obtained.

Peer-review: Externally peer-reviewed.

\section{Authorship Contributions}

Concept: N.K., B.E., Design: N.K., B.E., Data Collection or Processing: N.K., Analysis or Interpretation: N.K., B.E., Literature Search: B.E., Writing:B.E.

Conflict of Interest: No conflict of interest was declared by the authors.

Financial Disclosure: The authors declared that this study received no financial support.

\section{References}

1. Weibel J, Fields WS. Tortuosity, coiling, and kinking of the internal carotid artery. I. etiology and radiographic anatomy. Neurology 1965;15:7-18.
2. Paulsen F, Tillmann B, Christofides C, Richter W, Koebke J. Curving and looping of the internal carotid artery in relation to the pharynx: frequency, embryology and clinical implications. J Anat 2000;197Pt 3:373-381.

3. Pancera P, Ribul M, De Marchi S, Arosio E, Lechi A. Prevalence of morphological alterations in cervical vessels: a colour duplex ultrasonographic study in a series of 3300 subjects. Int Angiol 1998;17:22-27.

4. Agrawal R, Agrawal SK. Dangerous anatomic variation of internal carotid artery - a rare case report. Int J Anat Var (IJAV) 2011;4:174-176.

5. Sacco S, Totaro R, Baldassarre M, Carolei A. Morphological variations of the internal carotid artery: Prevalence, characteristics and association with cerebrovascular disease. Int J Angiol 2007;16:59-61.

6. Sacco S, Totaro R, Baldassarre M, Carolei A. Morphological variations of the internal carotid artery: Prevalence, characteristics and association with cerebrovascular disease. Int J Angiol. 2007;16:59-61. 